\title{
Контролінг як ефективний інструмент управління підприємством
}

\begin{abstract}
Важливою умовою забезпечення успішного функціонування підприємства і його прибуткової діяльності є застосування ефективних методів управління. Одним із таких методів є впровадження системи контролінгу для реалізації завдань тактичного й стратегічного менеджменту. Метою статті є обтрунтування засад формування сучасної концепиї контролінгу, заснованої на новій парадигмі управління, щцо забезпечує динамічний розвиток підприємства в довгостроковій перспективі. На підставі аналізу літературних джерел автором встановлено, що контролінг пов'язує, координує, узгоджує, контролює діяльність усіх функціональних одиниць підприємства з метою адаптації їхньӧ діяльності до змінних зовнішніх умов, здійснює інформаційне забезпечення прийняття оптимальних управлінських рімень. Систематизовано функиії контролінгу, через виконання яких досягаються планові завдання діяльності організачї, досліджено етапи побудови системи контролінгу на підприємстві для розробки і реалізаџії раџіональних цілей розвитку. Система передбачає чітке дотримання принщиипу відповідності повноважень видам управлінських впливів, принципу єдності ијілей, а також принципу підпорядкування методів і форм діяльності завданням управління підприємством. Для забезпечення ефективної роботи підприємства й отримання позитивного фінансового результату доцільно звернути увагу на інструменти та методи контролінгу. Обтрунтовано, щуо контролінг є сучасною концепцією, яка базуеться на основних положеннях нової парадигми управління. Нова парадигма управління характеризується наступними основними рисами: підприємство розглядається як відкрита система у взаємодї з його зовнішнім середовищем; основною метою діяльності вважається задоволення потреб споживачів у якісних товарах $i$ послугах; спостерігається зростання ијінності інтелектуальної праці в колективі.
\end{abstract}

Ключові слова: контроль, контролінг, управління підприємством, менеджмент, витрати, доходи, прибуток, управлінський облік.

DOI https://doi.org/10.33146/2307-9878-2019-4(86)-119-123

O.Yu. SOVA

(National University of Life and Environmental Sciences of Ukraine, Kyiv, Ukraine)

\section{Controlling as an Effective Enterprise Management Tool}

An important condition for ensuring the successful operation of the enterprise and its profitable activities is using the effective management methods. One such method is the introduction of a controlling system for the implementation of tasks of tactical and strategic management. The purpose of the article is to provide proposals for the formation of a modern concept of controlling based on a new management paradigm, which ensures the enterprise's long-term dynamic development. Based on the analysis of literary sources, the author found that controlling connects, coordinates, coordinates, controls the activity of all functional units of the enterprise in order to adapt their activity to changing external conditions, and provides informational support for making optimal management decisions. The article systematizes the functions of controlling, through which the planned tasks of the organization's activity are achieved. The stages of construction of the system of controlling at the enterprise for the development and realization of rational development goals are investigated. The system envisages a clear adherence to the principle of compliance of powers with the types of managerial influences, the principle of unity of goals, the principle of subordination of methods and forms of activity to the tasks of enterprise management. In order to ensure the efficient operation of the enterprise and obtain a positive financial result, it is advisable to pay attention to the tools and methods of controlling. Controlling is substantiated as a modern management concept based on the basic principles of the new paradigm. The new management paradigm is characterized by the following basic features: an enterprise is viewed as an open system in interaction with its external environment; the main purpose of the activity is to meet the needs of consumers in quality goods and services; there is an increase in the value of intellectual work in the team.

Keywords: control, controlling, enterprise management, expenses, income, profit, management accounting.

Сова Олена Юріївна, доцент кафедри виробничого та інвестиційного менеджменту Національного університету біоресурсів і природокористування України (м. Київ), кандидат економічних наук, доцент. 
Постановка проблеми. Функціонування підприємств та організацій відбувається в умовах постійно зростаючої конкуренції, швидко змінюваних потреб покупців, підвищеної соціальної відповідальності, обмеженості ресурсів і взаємозв'язку між всіма суб'єктами економіки. Посилення нестабільності ринкового організаційно-економічного середовища зумовлює необхідність перегляду системи управління підприємством, вивчення нових підходів та ефективних механізмів менеджменту, заснованих на використанні результатів теорії прийняття рішень, математичного прогнозування, інформаційного моделювання, реінжинірингу бізнес-процесів, теорії систем, CASE-технології.

Управління підприємством у сучасних умовах господарювання вимагає комплексного вирішення багаточисленних проблем, обумовлених як зовнішніми, так і внутрішніми факторами. Ефективність системи менеджменту полягає в умінні передбачити виробничу та комерційну ситуацію, попередити негативний вплив ендогенних і екзогенних факторів, вжити заходів щодо мінімізації витрат, забезпечити досягнення поставлених цілей i, перш за все, в отриманні позитивного фінансового результату діяльності підприємства запланованого прибутку.

Ці обставини вимагають формування нових підходів до управління бізнес-одиницями та інструментів їх впровадження. В якості такого інструменту на сьогоднішній день виступає контролінг. Контролінг як нове явище в теорії $\mathrm{i}$ практиці сучасного управління підприємством, яке виникло на перетині економічного аналізу, планування, управлінського обліку і менеджменту, переводить процес управління підприємством на якісно новий рівень.

Аналіз останніх досліджень і публікацій. Дослідженню теоретичних питань становлення контролінгу як дієвої ланки менеджменту i практичних аспектів впровадження системи контролінгу на підприємстві присвячено багато праць вітчизняних науковців. Зокрема, розглядаючи сутність контролінгу, В.Я. Плаксієнко, I.M. Назаренко, А.І. Орєхова наголошують, що він $є$ не лише інструментом управління витратами бізнесу, але i координатором інших сегментів управління підприємством [6]. А В.В. Ходзицька [10] основним об'єктом контролінгу називає все ж управління витратами 3 акцентом на стратегічні завдання менеджменту на підприємстві. В.О. Шпильова підкреслює, що контролінг орієнтований на підтримку процесів прийняття рішень і ефективний саме для нестабільного, постійно мінливого економічного середовища [11]. М.Д. Бедринець, T.М. Денега вбачають у системі контролінгу потужний інструмент фінансового антикризового управління підприємством [1]. Потребу в інтеграції різних аспектів управління бізнес-процесами в організаційну систему Н.М. Михайличенко, А.О. Токарева [5] пов'язують 3 виникненням i впровадженням сучасних принципів розробки та
Аудит, аналіз і контроль

прийняття управлінських рішень на основі концепції контролінгу.

В той же час, зважаючи на низький рівень використання контролінгу на практиці, дослідження його переваг і недоліків, особливостей формування ефективного механізму контролінгу як важливого чинника зростання комерційного потенціалу підприємств, залишається актуальним.

Мета статті - обгрунтувати засади формування концепції контролінгу як частини сучасної системи менеджменту, заснованої на новій парадигмі управління, що забезпечує довготривалий стійкий розвиток підприємства.

Методика дослідження. Достовірність та обгрунтованість дослідження забезпечено використанням методів логічного узагальнення (для уточнення економічної сутності поняття «контролінг»); порівняльного аналізу (для деталізації функцій контролінгу); наукового абстрагування (для вивчення схеми впровадження системи контролінгу на підприємстві); табличного методу (для унаочнення масиву теоретичної інформаціі).

Виклад основного матеріалу. Управлінські системи, що дозволяють швидко реагувати керівникам підприємств на зміни зовнішнього середовища організації, набувають особливої актуальності в умовах нестабільності, якою характеризується сучасний ринок. Інтегровані підходи, що здатні забезпечити відповідність мінливих умов запитам споживачів, адекватну відповідь на виклики зростаючої конкуренції та відповідність принципам соціальної відповідальності бізнесу в умовах обмеженості ресурсів - стають вельми затребуваними. Таким підходом може виступати контролінг.

Для вітчизняних підприємств контролінг є все ще новим і мало застосовуваним інструментом, так як впровадження системи контролінгу на підприємстві дорогий i трудомісткий процес. Як інструмент менеджменту він виник на перетині завдань управлінського обліку, планування, економічного аналізу та менеджменту.

При цьому доводиться констатувати, що канонічного визначення контролінгу не існує. Під ним можна розуміти систему управління організацією, в основі якої лежить збір, аналіз інформації та подальше іiі використання для досягнення поставлених цілей, а також підвищення ефективності діяльності організації в довгостроковій перспективі.

Найбільш лаконічне економічне визначення інтерпретує «контролінг» в якості категорії «управлінський облік», і може використовуватися як синонім цього поняття [8, с. 765]. Одним із головних завдань управлінського обліку $є$ своєчасне забезпечення системи менеджменту організації інформацією про витрати підприємства, витрати i результати діяльності в потрібних аналітичних ракурсах для прийняття управлінських рішень 3 метою підвищення ефективності діяльності установи за рахунок внутрішніх резервів. 


\section{Аудит, аналіз і контроль}

М.М. Бердар [2, с. 41] розглядає контролінг як координацію систем планування, контролю та інформаційного забезпечення для збільшення вартості компанії.

Інше трактування терміну «контролінг» визначає його як новий напрям, нову концепцію розвитку сучасного менеджменту [3, с. 250].

Даний підхід до системного управління підприємством дозволяє забезпечити успішне функціонування організаційної системи в довгостроковій перспективі шляхом:

- адаптації стратегічних цілей підприємства до мінливих умов зовнішнього середовища;

- узгодження оперативних планів зі стратегічним планом розвитку організаціі;

- координації та інтеграції оперативних планів по окремих бізнес-процесах;
- створення системи забезпечення різних рівнів управління підприємства вчасно-тимчасовою i повною інформацією;

- створення системи контролю над виконанням планів, коригування їх змісту і термінів виконання;

- адаптації організаційної структури управління підприємством 3 метою підвищення іiі гнучкості та здатності швидко реагувати на мінливі вимоги зовнішнього середовища.

Для реалізації кінцевої мети підприємства контролінг взаємопов'язує всі функції менеджменту, інтегрує і координує їх, при цьому не підміняє собою управління, а переводить його на якісно новий рівень. Головна мета контролінгу - це вдосконалення системи управління розвитком підприємства.

Реалізація контролінгу на підприємстві здійснюється через наступні функції (табл. 1).

Таблиия 1

\section{Характеристика основних функцій контролінгу на підприсмстві}

\begin{tabular}{|c|l|l|}
\hline № & \multicolumn{1}{|c|}{ Назва } & \multicolumn{1}{|c|}{ Сутність функції } \\
\hline 1. & Інформаційна функція & $\begin{array}{l}\text { - створення інтегрованої інформаційної системи, що дозволяє забезпечувати } \\
\text { менеджмент релевантними відомостями в межах іх компетенцій, а також } \\
\text { ефективну взаємодію менеджерів у системі управління }\end{array}$ \\
\hline 2. & Функція контролю & $\begin{array}{l}\text { - кількісне визначення цільових орієнтирів, допустимого відхилення від них і } \\
\text { аналіз досягнення результатів за фактичними показниками }\end{array}$ \\
\hline 3. & Функція планування & $\begin{array}{l}- \text { створення системи планування в організації, ії методичне забезпечення, } \\
\text { оцінка досяжності поставлених цілей }\end{array}$ \\
\hline 4. & Функція регулювання & - визначення і проведення коригувальних заходів, здійснення моніторингу \\
\hline 5. & Аналітична функція & $\begin{array}{l}- \text { вивчення отриманої інформації з метою виявлення чинників, що впливають } \\
\text { на відхилення цільових показників від норми, оптимізація розподілу ресурсів } \\
\text { на основі отриманих даних }\end{array}$ \\
\hline 6. & Функція координації & $\begin{array}{l}- \text { узгодження всіх бізнес-процесів підприємства, а також роботи його } \\
\text { підрозділів }\end{array}$ \\
\hline 7. & Функція інтеграції & $\begin{array}{l}- \text { забезпечення збалансованості різних функціональних планів в рамках } \\
\text { загального фінансового плану установи }\end{array}$ \\
\hline
\end{tabular}

Джерело: узагальнено автором на основі [4; 7].

Впровадження системи контролінгу на підприємстві передбачає використання конкретних інструментів i методів менеджменту, набір яких різний для кожного 3 видів контролінгу стратегічного й оперативного.

Стратегічний контролінг спрямований на те, щоб обгрунтувати цілі підприємства і виявити способи їх досягнення. Даний вид контролінгу передбачає застосування таких інструментів, як збалансована система показників, SWOT-аналіз, крива досвіду i життєвого циклу організації, портфельний аналіз, матричні інструменти оцінки ринкового становища, сценарний аналіз, GAP-аналіз, Make-or-Buy-аналіз.

Оперативний контролінг спрямований на досягнення поставлених цілей найбільш ефективним способом. При цьому стратегія і цілі не підлягають зміні. Інструменти, що використовуються в оперативному контролінгу, - це управлінський облік і бюджетування, аналіз точки беззбитковості, АВСаналіз і XYZ-аналіз, факторний і фінансовий аналізи.

Формування системи контролінгу найчастіше відбувається без дотримання логічної послідовності, фрагментарно, або без належного обгрунтування. Як результат - невиправдані витрати ресурсів, низька ефективність діяльності підприємства.

Схему впровадження системи контролінгу на підприємстві можна зобразити у вигляді алгоритму, що складається 36 етапів:

1) Виявлення об'єктів контролінгу.

2) Визначення напрямків впливу на кожний об'єкт інструментами оперативного та стратегічного контролінгу, які мають різний зміст, періодичність і тривалість.

3) Ранжування об'єктів, на які спрямована система контролінгу, за пріоритетністю для розвитку підприємства.

4) Встановлення нормативних значень для кожного показника, що характеризує об'єкт управління в системі контролінгу.

5) Створення системи моніторингу показників діяльності компаніі.

6) Систематичний аналіз даних, отриманих в результаті моніторингу, виявлення «критичних 
точок» i проведення коригувальних заходів для запобігання можливих проблем.

Професійно побудована система контролінгу охоплює всі напрями діяльності організації, дозволяє здійснювати координацію роботи структурних підрозділів, передбачати можливі проблеми і здійснювати превентивні заходи по їх недопущенню, а також сприяє забезпеченню стійкості фінансового стану компанії. На підприємствах, які впроваджують систему контролінгу, він стає основним джерелом інформації для прийняття управлінських рішень, охоплюючи методи планування, прогнозування, аналізу та контролю, управління персоналом.

Таким чином, роль контролінгу як ефективного інструменту управління організаціями полягає в
Аудит, аналіз і контроль

обгрунтуванні заходів управлінського впливу, у формуванні механізмів зворотного зв'язку, організації інформаційних потоків у компанії, інтеграції процесів управління, а також вдосконалення системи внутрішньої звітності.

Елементи контролінгу є практично на кожному підприємстві, але вони розрізнені i через роз'єднаність не призводять до синергетичного ефекту в загальній системі управління. Система контролінгу (рис. 1) має базуватися на логічно поєднаних елементах, що охоплюють управлінські та організаційні аспекти діяльності господарюючої організації.

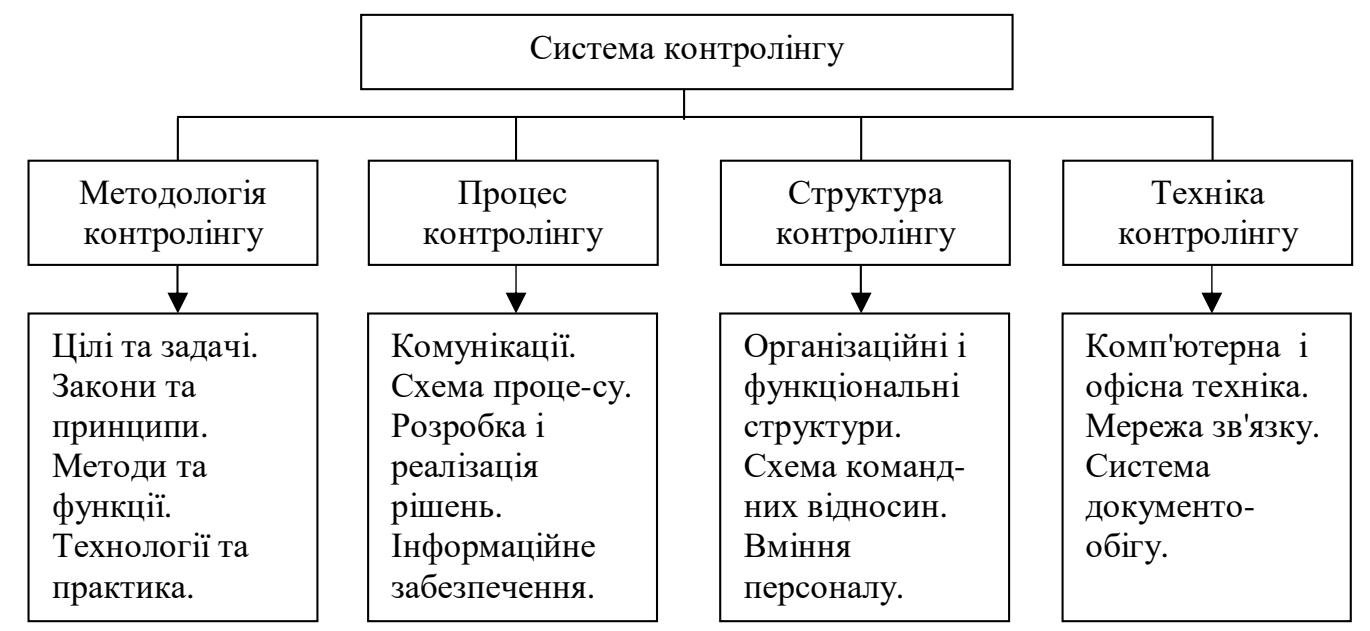

Рис. 1. Композиція елементів системи контролінгу на підприсмстві Джерело: структуровано автором на основі [4; 7].

Завданням стратегічної політики розвитку підприємства повинний бути допуск носіїв унікального інтелектуального і людського капіталу в процеси підготовки варіантів управлінських рішень та комунікацій. Одним із кінцевих результатів впровадження контролінгу на підприємстві $\epsilon$ скорочення часу реакції економічного механізму на зміну зовнішнього i внутрішнього середовища, a також скорочення управлінських ризиків, пов'язаних 3 нераціональним характером прийнятих менеджерами різних ланок рішень.

Побудова моделі контролінгу з описом ії основних елементів у взаємозв'язку і взаємодії дозволить надалі ефективно вбудувати службу контролінгу в систему управління підприємством, визначити цілі, принципи та функції ऑiі діяльності, сферу повноважень, що сприятиме досягненню стратегічних i тактичних цілей підприємства.

У зв'язку зі зміною курсу світової економіки, концепція підприємницького менеджменту також зазнає різких трансформацій.

Цифровізація, штучний інтелект і роботизація стануть головними драйверами світової економіки до 2030 року. Економічне зростання буде пов'язане із цілковитою автоматизацією процесів, збільшенням продуктивності праці та впровадженням принципово нових бізнес-моделей i технологій, як-от цифрові платформи, цифрові екосистеми, програма «Індустрія 4.0» [9].

Нову парадигму контролінгу охарактеризуємо такими рисами:

- позиціонування підприємства як «відкритої» системи, що функціонує в єдності з внутрішнім i зовнішнім середовищем;

- визнання основною метою діяльності господарюючих суб'єктів - якість продукції i задоволення споживачів, а не зростання обсягів виробництва;

- адаптивність до зовнішнього середовища;

- зростання цінності фахівців, що володіють широким спектром професійних знань, умінь i навичок;

- підвищення ролі організаційної культури і мотивації співробітників.

Аналіз сучасних концепцій менеджменту дозволив виділити основні принципи управління, спрямовані на формування конкурентних переваг i сталий розвиток підприємства: діяльність підприємства повинна бути орієнтована на потреби i, в перспективі, на формування довгострокових партнерських взаємовідносин зі споживачами.

Управління якістю слід розглядати як цільову підсистему, де висококваліфікований персонал відіграє ключову роль в забезпеченні конкурентоспроможності та стратегічного розвитку 
Аудит, аналіз і контроль

підприємства. Людина $є$ системоутворюючим елементом виробничої i інформаційноінтелектуальної діяльності підприємства, а організаційна культура $є$ основним стимулюючим фактором персоналу. Оптимізація матеріальних i фінансових ресурсів 3 урахуванням соціального ефекту, екологічної та енергетичної безпеки дозволить підвищити ефективність роботи підприємства як соціально-економічної системи.

Висновки. Аналіз підходів до системного управління організаціями засвідчує, що на сьогоднішній день на вітчизняних підприємствах доступний до використання широкий спектр інструментів тактичного та стратегічного контролінгу, але відсутня ефективна композиційна система, яка забезпечить підтримку виконання управлінських завдань.

Проведене дослідження дозволило систематизувати елементи системи контролінгу на підприємстві, які включають такі блоки, як методологія контролінгу, процеси, структура та техніка контролінгу. При пошуку напрямків удосконалення системи управління розвитком підприємства важливим $€$ синтез інструментів контролінгу для ефективного протистояння підприємства змінам зовнішнього середовища.

Орієнтація управлінського процесу на досягнення цілей, які поставлені перед підприємством, спонукає до визначення схеми впровадження системи контролінгу для досягнення ефективності діяльності бізнес-одиниць. Це дозволило виділити 6 етапів формування нової парадигми контролінгу на підприємстві.

Отже, для вирішення завдань управління треба впроваджувати на підприємствах систему контролінгу, що встановлює взаємозв'язок між цілями, суб'єктами і об'єктами контролінгу, його інструментарієм та інформаційною базою підприємства, призначена для забезпечення сталого розвитку підприємства в мінливому зовнішньому середовищі.

Подальші дослідження слід проводити в напрямку визначення місця служби контролінгу в структурі управління підприємством, формулювання цілей іiі створення, функцій і способів їхньої реалізації.

\section{4 Список використаних джерел}

1.Бедринець М. Д., Денега Т. М. Контролінг в системі фінансового антикризового управління підприємством. Збірник наукових праць Університету державної фіскальної служби Украӥни. 2018. № 2. С. 15-27.

2. Бердар М. М. Контролінг як сучасна концепція управління промисловим підприємством. Економіка та держава. 2016. № 11. С. 39-43.

3. Кіпіоро I. М. Формування системи контролінгу на підприємстві. Наукові праці Кіровоградського національного технічного університету. Економічні науки. 2012. Вип. 22. С. 250-254.

4. Маркіна I. А., Таран-Лала О. М., Гунченко М. В. Контролінг для менеджерів: навч. посіб. Київ: «Центр учбової літератури». 2013. 304 с.
5. Михайличенко Н. М., Токарева А. О. Проблеми та перспективи впровадження контролінгу як сучасного інструменту управління підприємством. Научный вестник Донбасской государственной машинострочтельной академии. 2017. № 1. С. 176-181.

6. Плаксієнко В. Я., Назаренко І. М., Орєхова А. І. Наукове обгрунтування інструментарію контролінгу в системі управління економічним потенціалом підприємства. Бізнес Інформ. 2018. № 3. С. 375-380.

7. Портна О. В. Контролінг: підручник. Львів: «Магнолія 2006». 2013. 264 с.

8. Сирцева С. В., Кушнірук В. С., Бондаренко I. О. Управлінський облік як основа контролінгу в системі управління аграрними підприємствами. Інфраструктура ринку. 2019. № 19. С. 763-767.

9. Український інститут майбутнього. Офіційний сайт. URL: https://strategy.uifuture.org/prognoz-rozvitkusv\%D1\%96tovoi-ekonom\%D1\%96ki-do-2030e.html

10. Ходзицька В. В. Стратегічний контролінг як методичний інструментарій стратегічного управління витратами. Облік і фінанси. 2014. № 4 (66). С. 146-153.

11. Шпильова В. О. Інструменти контролінгу в системі фінансового антикризового управління. Агросвіm. 2017. № 17. C. 3-7.

\section{References}

1.Bedrynecj M. D., Denegha T. M. (2018). Kontrolingh v systemi finansovogho antykryzovogho upravlinnja pidpryjemstvom. Zbirnyk naukovykh pracj Universytetu derzhavnoji fiskaljnoji sluzhby Ukrajiny. 2. 15-27.

2. Berdar M. M. (2016). Kontrolingh jak suchasna koncepcija upravlinnja promyslovym pidpryjemstvom. Ekonomika ta derzhava. 11.39-43.

3. Kipioro I. M. (2012). Formuvannja systemy kontrolinghu na pidpryjemstvi. Naukovi praci Kirovoghradsjkogho nacionaljnogho tekhnichnogho universytetu. Ekonomichni nauky. 22. 250-254.

4. Markina I. A., Taran-Lala O. M., Ghunchenko M. V. (2013). Kontrolingh dlja menedzheriv: navch. posib.. Kyiv: Centr uchbovoji literatury.

5. Mykhajlychenko N. M., Tokareva A. O. (2017). Problemy ta perspektyvy vprovadzhennja kontrolinghu jak suchasnogho instrumentu upravlinnja pidpryjemstvom. Nauchnyiy vestnik Donbasskoy gosudarstvennoy mashinostroitelnoy akademii. 1. 176-181.

6. Plaksijenko V. Ja., Nazarenko I. M., Orjekhova A. I. (2018). Naukove obgruntuvannja instrumentariju kontrolinghu v systemi upravlinnja ekonomichnym potencialom pidpryjemstva. Biznes Inform. 3. 375-380.

7. Portna O. V. (2013). Kontrolingh: pidruchnyk. Ljviv: Maghnolija 2006.

8. Syrceva S. V., Kushniruk V. S., Bondarenko I. O. (2019). Upravlinsjkyj oblik jak osnova kontrolinghu $\mathrm{v}$ systemi upravlinnja aghrarnymy pidpryjemstvamy. Infrastruktura rynku. 19. 763-767.

9. Ukrajinsjkyj instytut majbutnjogho. Oficijnyj sajt. URL: $\quad$ https://strategy.uifuture.org/prognoz-rozvitkusv\%D1\%96tovoi-ekonom\%D1\%96ki-do-2030e.html

10. Khodzycjka V. V. (2014). Strateghichnyj kontrolingh jak metodychnyj instrumentarij strateghichnogho upravlinnja vytratamy. Oblik i finansy. 4 (66). 146-153.

11. Shpyljova V. O. (2017). Instrumenty kontrolinghu v systemi finansovogho antykryzovogho upravlinnja. Aghrosvit. 17. 3-7. 